\title{
Teaching Speaking Through Storytelling
}

\author{
Rodi Hartono ${ }^{1 *}$, Mukhaiyar ${ }^{2}$, Rusdinal $^{3}$, and Azwar Ananada ${ }^{4}$ \\ ${ }^{1}$ Post Graduate Students of Educational Science, Padang State University, Padang, West Sumatra, 25131, Indonesia \\ ${ }^{2,3,4}$ Lectures of Post Graduate Program, Padang State University, Padang, West Sumatra 25131, Indonesia \\ *Corresponding author. Email: rudi.stainkrc@gmail.com
}

\begin{abstract}
The research objective is to increase the students' speaking skill. The research is conducted to find out the effect of using storytelling to the students' speaking skill. The research design was quasi-experimental research, the respondents were students of SMP Negeri 2 Kerinci. 41 students divided into two groups (experimental class and control class). The instrument of the research was tests which were given before and after treatment. Experimental group was taught by using storytelling technique meanwhile control group was taught by using traditional technique. The result of the research showed that t-obtain $>\mathrm{t}$-table, $17.24>1.68$, so Null hypothesis was rejected. In other words, the students who were taught using storytelling technique achieved a better ability in speaking English than the students who were taught using traditional technique. It indicates that there is a significant difference in the experimental group compared to the control group. The result of the research concluded that there was a significant effect of using storytelling in students' speaking skills.
\end{abstract}

Keywords: teaching, speaking, storytelling

\section{INTRODUCTION}

English has four skills that have to be mastered by the students. There are listening, reading, speaking, and writing. Speaking is one of skill in English that has to be mastered by the students. In addition, speaking is a process conveying, sharing ideas and feeling orally. Murcia states that in academic settings, speaking is assumed to be the central means for learning new information and gaining access to alternative explanations and interpretation [1].

In learning English speaking, storytelling is a good strategy to be applied to beginner students in learning English. Teachers, in learning English in junior high schools often use pictures as a medium. The use of image or visualization media can increase the attention of students, making it easy to obtain information. Storytelling can entertain and arouse the enthusiasm of students in the learning process, so that students can learn with pleasure and are motivated to pay more attention to the material presented by the teacher. Students are involved in the learning process by using stories and following the plot of a story which they will later tell back to their friends according to the story told. Storytelling is an important part of learning, if students are involved and not only become spectators in the classroom. They are able to think logically and anticipate the story line that will happen next and find the true meaning of the story being told [2].
Hamilton and Weiss argue that storytelling in particular can improve expressive language skills and can stimulate innovative thinking. They believe that listening to stories can improve language skills such as vocabulary development, comprehension, sequencing, and story repetition. They also argue that storytelling can encourage creativity because it ignites students' imaginations and inspires them to tell stories and write their own stories[3].

The process of learning speaking skills that was carried out at SMP Negeri 2 Kerinci was still ineffective, because the teacher put more emphasis on reading and writing skills. Richards and Rodgers[4] stated speaking skills are neglected because teachers only focus more on increasing students' reading and writing skills, particularly in Translation-Grammar method. However, speaking is the most important, one that is indispensable for effective communication [5]. The main objective of teaching English is to give students the ability to use English effectively and correctly in communication[6]. However, it seems that students still cannot communicate in English fluently and accurately.

Language is a means of expression to convey ideas and ideas in communicating with others. Humans are required to convey messages and thoughts in a language that is understood by others, as mentioned in Surat Ar-Rahman verses 3-4: [7]. 


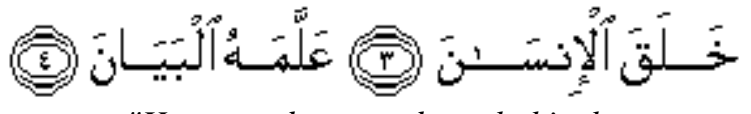

"He created man and taught him how to speak"

Speaking is one of the components of English language skills that must be learned by students before mastering other language skills. Speaking is often considered the most important of the four language skills even though they are interdependent. This, as stated by Penny Ur [8] that:

"People who know a language are referred to as 'speakers of that language' as if speaking including all other kinds of knowing, and many if not most foreign language learners are primarily interested in learning to speak".

The above quotation can be concluded that a person is said to be able to master English well measured by his/her ability to use the language itself in communicating. For that, it is necessary to carry out proper learning in order to achieve the stated goals. The learning process must be enjoyable for students as well as provide motivation.

Speaking skills are essentially productive and oral use skills that are done face to face [9]. Meanwhile, Brown stated that speaking skill is "an interactive process of constructing meaning that involves producing and receiving and processing information"[10]. The form and meaning depend on the context in which the speech appears which includes the respondents, the topic, and the conversation situation. Through speaking skills can help someone to express thoughts and ideas better than other language skills. The form and meaning were depending on the context in which the speech appears.

Meanwhile, Harmer said that the elements of speaking skills consisted of; language features and mental / social processes the ability to produce information. Language features include speech, speech tools, lexicons, grammar [11]. Finnochiaro and Bonomo revealed six important things in speaking skills, namely; (1) determine with whom to speak, (2) choose the right words, (3) choose meaningful words, (4) construct the right sentence, (5) determine the right situation, and (6) pronounce it with tongue right. [12]The habit factor in speaking also aims to provide opportunities for students to correct sentences that are not correct according to the language structure. This means that repeated speaking skills can create fluency in speech, master a lot of vocabulary, and grammar. So that students' speaking skills can be developed, it is better to use real situations (real life). The habit factor in speaking also aims to provide opportunities for students to correct sentences that are not correct according to the language structure. This means that repeated speaking skills can create fluency in speech, master a lot of vocabulary, and grammar. So that students' speaking skills can be developed, it is better to use real situations (real life). The habit factor in speaking also aims to provide opportunities for students to correct sentences that are not correct according to the language structure. This means that repeated speaking skills can create fluency in speech, master a lot of vocabulary, and grammar. So that the students' speaking skills can be developed, it is better to use real life situations.

In learning English speaking, storytelling is a good technique to be applied to beginner students in learning English. Teachers, in learning English in junior high schools often use pictures as a medium. The use of image or visualization media can increase the attention of students, making it easy to obtain information.

As explained by Haven, 1). Storytelling is a strong and effective element in an effort to improve and develop the four major language arts skills (reading, writing, listening, and speaking. 2). Information (both concepts and facts) is better remembered and longer when presented in story form. 3). Storytelling is a strong and effective interdisciplinary, cross-curriculum teaching. 4). Positive storytelling motivates students to learn. The stories focus the attention of students and learners to continue related studies 5). Storytelling is effective in building students' self-confidence and selfesteem. 6). Storytelling effectively engages and develops better imagination and creativity skills.7) Storytelling is attached to and entertains. 8). Storytelling creates empathy and a sense of connectedness. 9). Storytelling enhances analytical and problem-solving skills.10). Storytelling creates valuable links to society and heritage [13].

When creating a lesson-based story plan or syllabus, a teacher needs to learn what objectives that want to achieved and what activities will be used in the lesson but also how the activity starts and the activity ends with a fun story. These activities are known as preactivities in while activities and post activities. In the learning process storytelling is not only reading stories but also listening and speaking.

Students have to do each activity repeatedly before they begin to fully exploit their learning potential. Learning activities must be varied, comfortable learning environment, attractive so that they remain motivated to achieve the goals and benefits of learning. A teacher must plan each activity before going to class. It is also important to offer instructions and to communicate with students. When students know what to do, and how to do assignments, and complete 
activities, and provide feedback to students with some input on their success. [14]

There are several steps in carrying out storytelling learning, among others:

\section{Pre-Storytelling Activities}

There are two very important activities in prestorytelling activities for the teacher. They are introducing the topic and motivating the students to read or listen to the stories. The students begin to think about the story; they prepare their minds and show what they know about it. These activities help teachers anticipate problems with language and concepts and provide space for activities before language teaching. Warming up is the relaxation activities for students. For example, speaking informally can build and maintain good relationships between teachers and students. The teacher asked the questions about topic of the lesson and the students guessed the title of the lesson topic.

\section{While- Storytelling Activities}

Storytelling is an important thing for students to create a story. Hearing and responding to a story told by others is a fun challenge for students. When students or learners create and tell a story that they make themselves, the language becomes their own[15].

With the increasing use of the whole language approach to reading, writing, and storytelling plays an important role in language learning. The steps in the while-storytelling activity are: 1) The teacher reads the story; 2) The teacher makes questions about the story; 3 ) Modeling the story; 4) Students answer questions.

\section{Post-Storytelling Activities}

There are some activities in this stage, it includes gathering, reviewing and summarizing lessons. They may be done in lessons or used as homework. They must provide opportunities to expand and consolidate the language or topics introduced through the story [16]. The stage activities can develop students' productive skills in learning to speak (Speaking), (ask and answer, role play, etc.) and Writing, (writing letters, making foster, etc.)

Follow-up activities provide a sense of pleasure and satisfaction to allow students to complete work in English. They can also gain self-confidence and it can create a more positive attitude towards learning English. Storytelling can bridge the gap between language theory and language use and also to connect the classroom to the outside world. Some activities do not always have a very large language element but are still important in creating feelings among students who learn English means fun and creative activities.
Students will be much more involved and motivated in the learning process when they see that their hard work in learning is rewarded. That is why follow-up activities are very important for students.

\section{METHOD}

The research design was experimental research. According to Cresswell, experiment is test an idea (or practice or procedure to determine whether it influences an outcome or dependent variable [17]. An experimental design is one in which study participants are randomly assigned to experimental and control groups. The aims of educational experimental research are search the effect of treatment toward the students' activities in the classroom [18]. The design of this research was quasi experimental. A quasi experimental is an empirical interventional study which use to estimate the causal impact of an intervention on target population without random assignment.

Furthermore, the researchers used two classes as sample. The first class was experiment class where the researchers used Storytelling technique as the treatment, which the second class was control class where the researchers used conventional technique as the treatment. In the experimental class, the students administrated with pre-test at the begining of the teaching process to know the students speaking skill. Then, at the middle, there is a treatment. During treatment, the researchers used Storytelling as the technique of teaching speaking. At the end of the teaching process, there is post test in order to know the effect of Storytelling towards students' speaking skill.

\section{RESULT AND DISCUSSION}

\subsection{Control Class}

The control class was a class taught without using storytelling technique. In this class, there were 20

Students. The researchers gave pre-test for the control class to know the students' score before teaching learning processed had done about speaking skill. Then, the researchers used 3 Raters to calculate the students speaking score.

From the first rater, the mean score was 41.8 of pre-tests of control class. It consisted 2 students got fair category, 11 students got weak category and 7 students got poor category. Besides, from the second rater the mean score of pre-tests in control was 43. It was consisted of 3 students got fair category, 11 students got weak category and 6 students got poor category. Then, from third rater the mean score of students pre-test in control class was 43 . It was consisted of 3 students got 
fear category, 11 students got weak category and 6 students got poor category.

A post-test of control class purposed to know outcomes learning the speaking was taught without using storytelling technique. The researchers gave posttest to the control class to know the students' last score after teaching learning process had done. Then, the researchers used 3 raters to calculate the students' speaking score.

The first raters' $t$ mean score of post-tests in control class was 66,4 . It was consisted of 3 students got good category and 17 students got fair category. The second rater, the mean score was 66,6 . It was consisted of 3 students got good category, 16 students got fear category and 1 student got weak category. Then, the third rater the mean score was 66,6 . It was consisted of 3 students got good category, 16 students got fear category and 1 student got weak category.

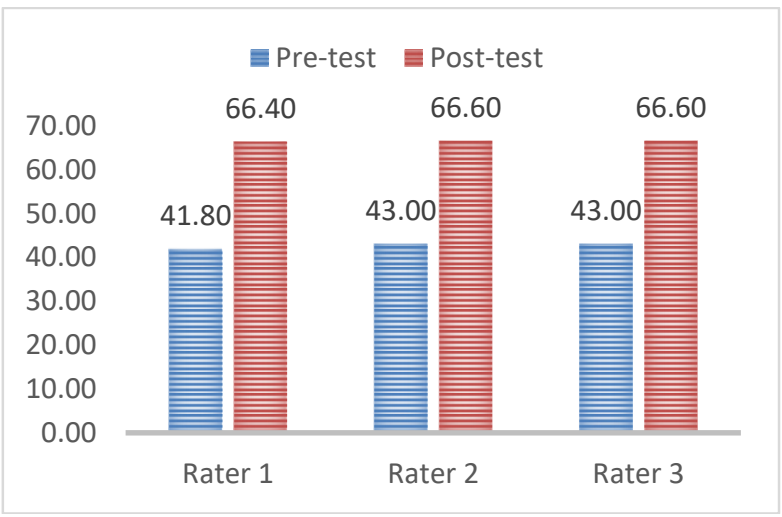

Figure 1. The result of students' speaking score of control class for pre-test and post-test.

\subsection{Experiment Class}

The experiment class was taught by using Storytelling technique. The students consisted of 21 students in this class. The researchers gave pre-test to the students of experiment class to know the students' score before teaching learning by using Storytelling technique. Then, the researchers used 3 raters to calculate the students score of speaking tests in pre-test of experiment class.

From the first rater the mean score of pre-tests in experiment class was 41.90. It was consisted of 2 students got fair category, 12 students got weak category and 7 students got poor category. Besides, the mean score of pre-tests in experiment class from second rater was 42.29. It was consisted of 2 students got fear category, 12 students got weak category and 7 students got poor category. Then, the mean score of pre-tests in experiment class from third rater was 42.29. It was consisted of 2 students got fear category, 12 students got weak category and 7 students got poor category.

A post-test of experiment class was a class purposed to know the outcome of the effect of using Storytelling technique. The researchers gave the posttest to the experiment class to know the students' last score after teaching learning process by using Storytelling technique. To look how far the improvement the score and then compared to the students' score was gotten from the control class score, the researchers used 3 raters to calculate students' speaking score in post-test.

From the first rater the mean score of post-tests in experiment class was 90.10. 13 students were in very good category and 8 students were in good category. Besides, from the second rater the mean score of posttests in experiment class was 90.10. 13 students were in very good category and 8 students were in good category. Then, from third rater the mean score of posttests in experiment class was 91.24. 16 students were in very good category and 5 students were in good category.

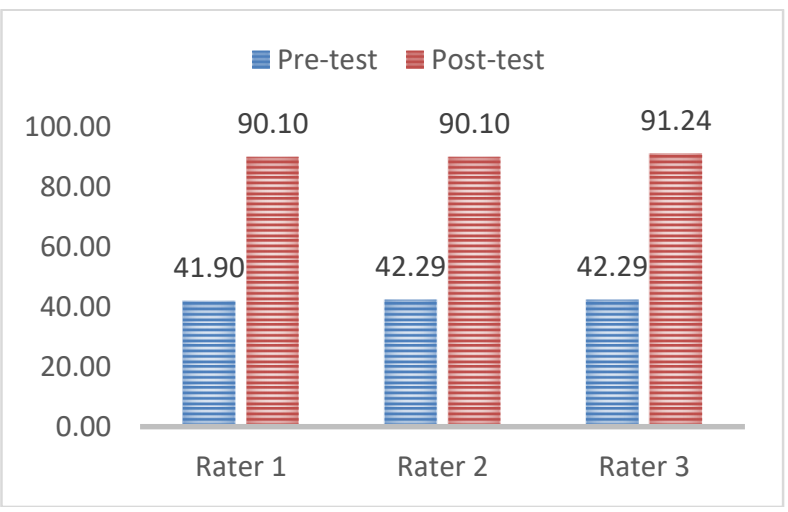

Figure 2. The result of students' speaking score of experiment class for pre-test and post-test.

Therefore, based on the both score from control and experiment classes, the average of score from students who was taught using storytelling technique was higher. It can be concluded that using storytelling technique toward students' speaking skill was successful.

\subsection{Reliability Test}

Inter-rater Reliability test was done to avoid of subjectivity on scoring of the speaking test of students. Besides, the researcher was done the reliability test using Fleiss' Kappa formula by inter-rater reliability. The following were the results of the reliability test from three raters that had scored the students speaking test. 
Table 1. Reliability Inter-rater Test Result

\begin{tabular}{|c|c|c|}
\hline Reliability Test & $\boldsymbol{k}$ & Interpretation \\
\hline $\begin{array}{c}\text { Pre-test of control } \\
\text { class }\end{array}$ & 0.773 & Substantial agreement \\
\hline $\begin{array}{c}\text { Post-test of control } \\
\text { class }\end{array}$ & 0.655 & Substantial agreement \\
\hline $\begin{array}{c}\text { Pre-test of } \\
\text { experiment class }\end{array}$ & 0.803 & $\begin{array}{c}\text { Almost perfect } \\
\text { agreement }\end{array}$ \\
\hline $\begin{array}{c}\text { Post-test of } \\
\text { experiment class }\end{array}$ & 0.732 & Substantial agreement \\
\hline
\end{tabular}

Based on the table above, the coefficient of reliability from each scoring of the tests were bigger than $0(k>0)$. Each result was categorized substantial and almost perfect agreement. According to Hughes, the ideal reliability coefficient was 1 . Since the scoring reliability the result closed to 1 , it meant the scoring of tests were reliable

\subsection{Normality and Homogeneity}

The normality of test is conducted to know the data of pre and post-test of control and experiment class is distributed normal or not. In this research, the researcher was done the normality test used ShapiroWilk Formula. To calculate the normality test using Shapiro-Wilk formula, there were some steps. First, the researcher determined the value $\mathrm{D}$ by making the table distribution and input students' scores from lowest to highest score, then calculate $\left(x_{i}-\bar{x}\right)^{2}$ to get the D value. After value $\mathrm{D}$ was gotten the next step calculated Value $\mathrm{T}$ by $a_{i}\left(x_{n-i+1}-x_{i}\right)$, and the last step was determining the normality of data by the Shapiro-Wilk formula. Moreover, the data was distributed normal if the $\mathrm{P}$ value $>5 \%$, so $H_{0}$ was received; $H_{a}$ was rejected (Table 2).

From the table above, it showed that the both scores of control and experiment classes were normally distributed, $H_{0}$ was received; $H_{a}$ was rejected, because $\mathrm{P}$ Value was $>5 \%$

Homogeneity test purposed to see the whether the data or sample in both classes are homogenous or not. The classes were homogenous if $F_{\text {Count }}<F_{\text {Table }}$. So, variance value was homogenous. To calculate the $F$ value, firstly the researcher counted the standard deviation of post-test experiment and control class scores. Standard deviation $\left(S_{1}\right)$ of post-test control was 7.37 and standard deviation $\left(S_{2}\right)$ of post-test experiment was 6.72 . Then, to get $F$ value, the researcher counted the Homogeneity test by $\mathrm{F}$ formula as follows. So, in this research, the researchers used $\mathrm{F}$ formula.

$$
\begin{aligned}
F & =\frac{s_{1}{ }^{2}}{s_{2}{ }^{2}} \\
F & =\frac{\text { the biggest varience }}{\text { the smallest varience }} \\
F & =\frac{6,76^{2}}{6,65^{2}} \\
& =\frac{45,90}{44,22} \\
& =1.04
\end{aligned}
$$

From the calculation, it can be seen that $F_{\text {count }}<F_{\text {table }}(1.04<2.16)$. Based on criteria, it can be concluded that $H_{0}$ was accepted. It meant that the sample in control and experiment classes were homogeneous.

Table 2. Normality Test

\begin{tabular}{|c|c|c|c|}
\hline Normality Test & $\begin{array}{c}\text { P } \\
\text { Value }\end{array}$ & $\boldsymbol{a}$ & Statements \\
\hline $\begin{array}{c}\text { Pre-test of control } \\
\text { class }\end{array}$ & 0.93 & 0.05 & $\begin{array}{c}\text { Scores were } \\
\text { normally } \\
\text { distributed }\end{array}$ \\
\hline $\begin{array}{c}\text { Post-test of } \\
\text { control class }\end{array}$ & 1.14 & 0.05 & $\begin{array}{c}\text { Scores were } \\
\text { normally } \\
\text { distributed }\end{array}$ \\
\hline $\begin{array}{c}\text { Pre-test of } \\
\text { experiment class }\end{array}$ & 0.96 & 0.05 & $\begin{array}{c}\text { Scores were } \\
\text { normally } \\
\text { distributed }\end{array}$ \\
\hline $\begin{array}{c}\text { Post-test of } \\
\text { experiment class }\end{array}$ & 0.91 & 0.05 & $\begin{array}{c}\text { Scores were } \\
\text { normally } \\
\text { distributed }\end{array}$ \\
\hline
\end{tabular}

\subsection{Hypothesis Testing}

After scoring the students' speaking test, to see whether significant effect of using Storytelling technique toward students' speaking skill, in this research, the researchers used hypothesis test by T-Test formula, the analysis can be seen as follows.

$$
\begin{aligned}
t & =\frac{\bar{X}_{2}-\bar{X}_{1}}{s \sqrt{\frac{1}{n_{1}}+\frac{1}{n_{2}}}} \\
& =\frac{91,24-42,29}{\sqrt[8,86]{\sqrt{\frac{1}{21}+\frac{1}{20}}}} \\
& =\frac{48,95}{\sqrt[8,86]{0,10}} \\
& =\frac{48.95}{8,86(0,32)} \\
& =\frac{48.95}{2,84} \\
t & =17.24
\end{aligned}
$$

To get t-test result, the researchers calculated the result of mean score of pre and post-test in experiment class. The mean score of pre-tests in experiment class $\left(\bar{X}_{1}\right)$ was 42.29 the mean score of post-tests in experiment class $\left(\bar{X}_{2}\right)$ was 91.24. Then the students number of pre-test and post-test of experiment class 
were 21 , it meant both of $\left(n_{1}\right)$ and $\left(n_{2}\right)$ were 21 . Then, researchers calculated ' $\mathrm{S}$ ' value by formula as follows.

$$
\begin{aligned}
S^{2} & =\frac{\left(n_{1}-1\right) S_{1}{ }^{2}+\left(n_{2}-1\right) S_{2}{ }^{2}}{n_{1}+n_{2}-2} \\
& =\frac{(21-1) 10,55^{2}+(21-1) 6,76^{2}}{21+20-2} \\
& =\frac{(20) 111,30+(20) 45,70}{39} \\
& =\frac{226+914}{39} \\
& =\frac{3140}{39} \\
& =78,5 \\
S & =\sqrt{78,5} \\
& =8.86
\end{aligned}
$$

Testing criteria were as follows:

$t$ value was compared with the t $1-a$ value, at $0.05 a$ with $\mathrm{df}=n_{1}+n_{2}$ so $\mathrm{df}=21+20-2=39$ obtained:

$$
\begin{aligned}
& \mathrm{t} 1-a=\mathrm{t}(1-a)(\mathrm{n}-2) \\
& \mathrm{t} 1-a=(1-0.05)(41-2) \\
& \mathrm{t} 1-a=(0.95)(39) \\
& \mathrm{t} 1-a=1.68
\end{aligned}
$$

To determine whether the hypothesis of the research appropriate or not use the t-test, it obtained from the calculation of $\mathrm{t}$ was 17.24 and the $\mathrm{t} 1-a$ distribution with $a 0.05$ and df 39 was obtained t $1-a=$ 1,68 . Because $t_{\text {count }}>$ t $1-a(17.24>1.68) H_{0}$ was rejected.

It has been mentioned above that the calculation of t-test showed $t_{\text {count }}>t_{\text {table }}$. It meant that alternative Hypothesis $\left(H_{1}\right)$ was accepted and it had a significant effect of using storytelling technique toward students' speaking skill. Meanwhile null hypothesis $\left(H_{0}\right)$ was rejected and it had no significant effect of using storytelling technique toward students' speaking skill.

\section{CONCLUSIONS}

The research finding showed that the effect of using storytelling technique toward students' speaking skill at eight grades of SMP Negeri 2 Kerinci was effective. The result of the research can be seen by the student score of speaking tests of post-test of both classes.

The score of t-test showed that $t_{\text {count }}(17,24)$ was higher than $t_{\text {table }}(1,68488)$. The alternative $\left(H_{1}\right)$ was accepted and Null hypothesis $\left(H_{0}\right)$ was rejected. Since, the $t_{\text {count }}$ was higher than the $t_{\text {table }}$, there were significant difference in the achievement between students in class experiment who were taught using storytelling technique and students in control class who were not. The mean score of experimental groups was 91,24 and the mean score of control class was 66,6. It meant that the experiment class was better than the control class. The researchers concluded that there was any significant effect of using storytelling technique toward students' speaking skill at eighth grade of SMP Negeri 2 Kerinci.

\section{REFERENCES}

[1] Marianne Celce Murcia, Teaching english as a second or foreign language (3rd edition). Boston: Heinle 2001, p. 187

[2] Davies, Alison. Storytelling in the classroom. London: Paul Chapman Publishing A SAGE Publications Company. 2007.p.6

[3] Hamilton, M. \& Weiss, M. Children tell stories: a teaching guide. NY: Richard Owen Publishers, Inc. 1990

[4] Richards, J. C., \& Rodgers, T. S. Approaches and methods in language teaching. Cambridge: Cambridge University Press. 2001.

[5] Ur Penny. A Course in language teaching practice and theory. Beijing: Foreign Language Teaching and Research Press. 2000.

[6] Davies, P., \& Pearse, E. Success in english teaching. Oxford University Press 2000.

[7] Departmen Agama Republik Indonesia, Al Qur'an dan terjemahnya. Jakarta: Intermasa. 2008.

[8] Ur Penny. A course in language teaching practice and theory. Beijing: Foreign Language Teaching and Research Press. 2000.

[9] Widdowson; H.G. Teaching language as communication. Oxford: Oxford University Press. 1978: 54

[10] Brown, H. D. 2000. Principles of language learning and teaching (3rd Edition).Beijing: Foreign Language Teaching and Research Press.

[11] Harmer, Jeremy. The practice of English language teaching. Pearson Education Ltd. 2001.269-270

[12] Finnochiaro, Mary and Bonomo, Michael. The Foreign Language Learners: A Guide for Teachers. New York: Regents Publishing Company, Inc. 1978.

[13] Haven, K. F. Super simple storytelling: a can-do guide for every classroom, every day. Englewood, Colo.: Teacher Ideas Press. 2000: 18

[14] Brumfit, Christopher; Jayne Moon, \& Ray Tongue (eds). Teaching English to children: from practice to principle. London: Harper Collins Publishers. 1991: 189

[15] Wright, Andrew. Storytelling with chlidren. Oxford: Oxford University Press.1995.

[16] Ellis, G. \& Brewster, J. Tell it again: The new storytelling handbook for primary teachers. London: Penguin.2002: 17

[17] Jhon. W. Cresswel, Educational research: planning, conducting, and evaluating quantitative and qualitative research (University of NebraskaLincoln: Pearson 2012: 295.

[18] Mukhaiyar. Pengantar penelitian pembelajaran bahasa inggris. Padang: Suakbina Press. 2017 